\title{
Nordic home-sharing utopia: a critical analysis of Airbnb in Helsinki
}

\section{Salla Jokela ${ }^{\mathrm{a} *}$ and Paola Minoia ${ }^{\mathrm{b}}$}

${ }^{a}$ Faculty of Social Sciences, Tampere University, Tampere, Finland; ${ }^{b}$ Faculty of Social Sciences, University of Helsinki, Helsinki, Finland

*corresponding author, salla.e.jokela@tuni.fi, tel. +358-50-3182610

\section{To cite this article:}

Salla Jokela \& Paola Minoia (2020) Nordic home-sharing utopia: a critical analysis of Airbnb in Helsinki, Scandinavian Journal of Hospitality and Tourism, DOI: $\underline{10.1080 / 15022250.2020 .1774412}$

\section{Nordic home-sharing utopia: a critical analysis of Airbnb in Helsinki}

\author{
The proliferation of Airbnb listings has been studied in major tourist cities, but \\ much less is known about the phenomenon in Nordic cities. In this paper we have \\ examined the situation in Helsinki, the capital of Finland, which has been largely \\ unexplored in the research literature. Using our situated knowledge as an entry \\ point, this study is based on geostatistical analysis, qualitative analysis of Airbnb \\ listings, thematic conversations with experts and analysis of public discourses \\ through media, to illustrate how Airbnb listings are distributed within the city and \\ what perceptions and responses this phenomenon is generating. In the study, we \\ challenge the public narrative that portrays short-term renting of homes in \\ Helsinki as a form of sharing economy, as opposed to more destructive \\ developments in major European tourist cities.
}

Keywords: Airbnb, short term rentals, digital platforms, spatial analysis, public perception, housing policy, Helsinki

\section{Introduction and research questions}

The proliferation of Airbnb listings has been a major issue in tourist cities such as Barcelona, Lisbon and Venice, but the number of Airbnb listings is growing rapidly in 
many Nordic cities too. This is also the case in Helsinki, where Airbnb has gained ground along with the overall expansion of the hosting economy, since the first rentals were listed in 2010 (Nenakhova, 2018, p. 17). While the number of Airbnb listings in Helsinki is still relatively modest compared to big tourist cities and other Nordic capitals (2,599 in Helsinki; 11,887 in Copenhagen; 3,956 in Oslo; but only 2,301 in Stockholm according to https://www.airdna.co), it has grown rapidly, covering approximately one-fifth of the total accommodation capacity in Helsinki in 2017 (Mustonen, 2018a). The occupancy rate of the Airbnb listings has varied between 50\% and 77\%, with August being the busiest month (Mustonen, 2018a, 2018b).

Previous empirical studies based on spatial patterns of “Airbnbization” in some major tourist cities have shown the contribution of Airbnb to processes of gentrification of central neighbourhoods and financialization of housing (e.g. Arias Sans and Quaglieri Domínguez, 2016; Cocola-Gant and Gago, 2019), while Ioannides et al. (2019) have noted that short-term renting of homes also has an impact on host communities in cities with more diversified economic structures. Helsinki, the city under focus in our study, belongs to the latter type, as tourism is not yet a major activity, but is growing. As residents of Helsinki ourselves, rather than being external observers of the growing impact of Airbnb on the city, we have been questioning how this economy is spreading in the urban space, and how local residents and administrators perceive it. When confronted with cases where Airbnb is more evident, for instance in public meetings, participants’ replies have shown a belief on a Nordic self-regulative capacity to contain the phenomenon at an acceptable scale, in line with the Nordic brand neoliberal culture (Hilson, 2008; Julkunen, 2006; Rose, 1999). Through this paper, we aim to contribute to this discussion by documenting the "silent" rise of Airbnb and its impact on Helsinki's neighbourhoods in relation to other related 
phenomena that are occurring on different scales. Together, these phenomena have been transforming housing and residential neighbourhoods in ways that have not been fully acknowledged by either the majority of urban citizens, or the public authorities.

On the global scale, the driving phenomena include the heavy financial crisis of 2007-2009, the failure of manufacture industries, the digital revolution, and overall expansion of the travel economy, especially concentrated in areas felt to be safe, compared to locations that were popular during the 1990s but have been hit by political crises. On the national scale, platform tourism has emerged at the intersection of economic restructuring that has opened space for tourism, and the diffused digitalization of all service sectors. On the local scale, phenomena that can be observed especially in Helsinki involve real estate market rises (City of Helsinki Executive Office, 2019) and local urban planning policies less able to control and intervene directly in tourism than to count on individual entrepreneurial involvement. Finland's and Helsinki’s public authorities have acknowledged some of the possible disadvantages related to the dominance of Airbnb in tourism accommodation services, but at the same time, the city administration has been fostering an expansion of the supply without having to be involved directly in planning or having to convert residential functions into tourism exercises. This outsourcing of responsibility over the administered space by the involvement of private entities is a typical feature of the neoliberalization of the city (Crouch, 2016; Mosedale, 2016).

While touching on these ideas through public discourses, we have paid attention to how the diffusion of the home sharing economy is perceived and negotiated in neighbourhoods where short-term tourism rental is at an early stage and has not yet created obvious problems. By sharing economy, we refer to the generation of additional 
income through the sharing of underutilised resources such as homes or rooms (Martin, 2016). Although avoiding deterministic forecasts of over-tourism and residential conflicts that are already evident in many traditional tourism cities, the aim of our study was to analyse the recent growth and spatial distribution of Airbnb rentals. We have also reported on some changes that have already occurred in the most impacted districts of central Helsinki, and we have discussed the positions expressed by local administrators towards this new urban phenomenon.

We addressed these phenomena and the specific spatial formations that are produced in Helsinki through a multi-method empirical analysis. The study specifically examined: a) the multi-scale recent history of economic drivers that have accompanied the growth of ICT and tourism; b) the distinctive spatial characteristics and impacts that these changes are having in Helsinki; and c) the public debate framing this phenomenon, to understand the public authorities’ vision for its governance.

\section{Historical background of the rise of IT- platforms and tourism in Helsinki}

The rise of digital short-term rental platforms in Helsinki is entangled with wider economic, political and cultural changes at various interconnected scales. In Finland, resource-based industries played a key role in the industrialization of the society in the late 19th century and 20th century (Michelsen \& Kuisma, 1992). After the economic depression of the 1990s, state investments in research, development and higher education, as well as close collaboration between research and industries, started to pave the way for the rise of knowledge-based industries (Schienstock, 2007, p. 100; Kiander, 2001, p. 61). At the turn of the millennium, electronics became the biggest 
branch of industry and the Finnish Nokia Group developed into the world's largest mobile phone company (Jonung, Kiander \& Vartia, 2009). With Nokia’s fall in the early 2010s, causing an economic downturn, small Finnish companies started to develop new digital products that encouraged the Finnish state to foster digitalization also in other sectors, including tourism. Forenom and other new operators started their business through digital platforms, to provide short- and long-term rentals in major Nordic cities. Lately, Forenom has formed a partnership with Airbnb, making its offerings available also through the Airbnb platform (Airbnb, 2019).

The shift from resource-based industries toward knowledge-based forms of value production has unfolded in parallel with other political and economic changes in the Finnish society. Since the 1990s, a shift was more about the internationalization of the Finland's image that brought about significant changes in the urban scene (Häkli, 2005; Mäenpää 2005). These included the “economization of culture” and the “creative city” thinking (Mustonen, 2015; Landry, 2000). As a result, the City of Helsinki started to invest in harnessing and developing urban culture and lively festivals. The World Design Capital events in 2012 consolidated the idea of design-driven approach to urban development with design as a way of developing public services, building international networks and accelerating corporate growth (https://www.hel.fi/designhelsinki/en). At the same time, Helsinki's status as the World Design Capital increased its worldwide attractiveness towards potential tourists, who were willing to experience this new and “authentic” Nordic contemporary scenery. Design, both in the newly-restored outdoor landscape of the city centre with buildings devoted to public culture and the minimalist interiors of homes, reinforced the idea of Northern authenticity. Further tourism development has been supported by international rankings on happiness and other positive socio-cultural characteristics that portray Finnish people as a role model 
population internationally. Furthermore, a combination of urban sophistication and nature, typical of Finland and other Nordic countries, has contributed to developing Helsinki's image as the capital of an exotic but culturally empowered country. In this context, home-based tourism appears to be an organic way to be immersed in this overall Nordic experience.

These contemporary evolutions converge into making digital platforms the best possible venues for economic ventures especially in the tourism market. In the following sections, we will present how the growing economy of short-term rentals in Helsinki is developing and what transformations it has entailed from the point of view of the public debate and local authorities. Compared to other locations, where shortterm platform-based residences are seen as problematic and hotly debated, in Helsinki discussions have just started to emerge and have been generally positive. Examples like Venice, Barcelona or Berlin are seen as extreme as they are tightly associated with overtourism and therefore, they are far beyond the situation of Helsinki. On the contrary, Helsinki is considered underequipped in terms of tourist lodging capacity, and therefore, the public sector welcomes the intervention of diffused rooms for tourists in home spaces.

While some criticism has started to be expressed through the newspapers (e.g. Pajuriutta, 2019), the idea has persisted that Airbnb is facilitating the renting of underutilized rooms, allowing occasional income, especially for young people, while promoting multiculturalism and cosmopolitan opening of the city. With the current Covid-19 pandemic, and the tourism economy falling, Airbnb is also considered as a way to provide temporary housing for quarantined people, travellers unable to fly home, rentals for longer periods, or even for short-distance travellers (Laakso, 2020; 
Saastamoinen, 2020). However, the problems of Helsinki as a city with chronic residential deficits are generally overlooked within the debates on platform tourism; therefore, we believe that looking at the changed ratio of apartments' occupations in the city centre, during the last few years, deserves a more accurate study.

\section{Data and methods}

Our study is on how the home-sharing economy is perceived and negotiated in neighbourhoods that do not suffer from over-tourism, but where tourism rentals have been rapidly increasing. Our examination is based on a combination of GIS analysis, mapping and statistical analysis; qualitative analysis of Airbnb listings; our own situated knowledge as residents; and thematic conversations with experts. By using data triangulation, we have developed a deep understanding of recent spatial developments of short-term rentals in Helsinki, as well as responses to these developments.

GIS analysis and mapping have enabled us to identify those neighbourhoods that have been the most affected by Airbnb. We used a six-month subscription to the Property Performance data collected by AirDNA, a company tracking Airbnb listings performance worldwide with monthly updates. By listing, we refer to an item offered via the platform, whether it be a room or an entire apartment. We have mapped the number of Airbnb listings per square kilometre in Helsinki’s sub-districts and the streets with the most Airbnb activity in 2018. The streets were selected by hand based on the number of reserved nights in 200 x 200 metre cells. In addition, the historical data have enabled us to map the number of reserved nights in 200 x 200 metre cells between 2016 and 2019. Together, these mapping exercises have enabled us to identify the locations 
most heavily influenced by the phenomenon in terms of the density of the listings as well as their activity.

To clarify the implication of this phenomenon within the most influenced areas, either economically, i.e. relating the tourist with the housing market, or experientially for travellers staying in shared homes, we have conducted a systematic analysis of the listings posted in the Airbnb platform between May 2015 and September 2019. International studies have shown that in hyper-touristic areas, Airbnb as a sharing practice has become a rarity, and the listings are predominantly apartments especially renovated to serve tourists. By contrast, the public opinion in Helsinki has been that short-term rentals are dominated by non-professional local residents.

In order to find out whether this is still the current situation, we have conducted a more detailed analysis of those Airbnb listings that are located in the areas identified through the GIS analysis and mapping. We have followed the example of insideairbnb.com that provides critical data about the evolution of the platform-enabled market of private accommodations in various cities. The coverage includes many European cities, but Copenhagen is the only Nordic city. Indicators presented in insideairbnb.com for other cities include percentages of apartments versus rooms offered in relation to the overall listings, and the number of listings under the same hosts. Observing these two ratios is also interesting in the case of Helsinki, to confirm, or eventually challenge, the general perception of Airbnb serving as a model of the sharing economy and diffused entrepreneurships that we noticed in the public narrative.

Furthermore, we have considered the social context of the phenomenon by using ourselves as “research tools” in our research (Evans, 1988; Raento, 2009). This approach entails that our knowledge is situated, i.e. inevitably shaped by our social 
circumstances (Haraway, 1996; Rose, 1997). We acknowledge that our views are partial, but we draw on our experiences and lessons we have learned about our research topic through participation.

Our social positions in relation to short-term rentals in Helsinki are slightly different: one of us is a Finn, who has lived most of her life in Helsinki, while the other was born and raised in Venice, Italy and moved to Helsinki approximately 15 years ago. As a result, we have observed the development of short-term rentals in Helsinki from two perspectives: author X has observed Helsinki's situation in the context of the recent changes in Finnish society, whereas author Y has more directly compared it to what is commonly known as the "worst-case scenario" for other cities, paying attention to those characteristics that distinguish Helsinki from Venice and other major tourist cities. By positioning our study at the intersection of these two perspectives, we have been able to reduce the bias that might result from studying the phenomenon from the point of view of a single cultural and social background.

As residents of Helsinki, we have been involved in discussions and networks that are relevant to the development and governance of short-term rentals in Helsinki. We have been able to identify key actors in residents’ associations and build on existing trust and collaborations in our discussions with residents and city officials. Furthermore, our linguistic skills and knowledge about the cultural and social context in Finland have enabled us to follow the local media and analyse technical reports, as well as the ways in which they have informed public discourses and policy documents. 


\section{Cartographic analysis}

Based on the property performance data acquired from AirDNA

(https://www.airdna.co), Airbnb listings in Helsinki are concentrated in the central urban area that is connected by tramlines. The density of Airbnb listings is the highest in the districts of Kallio, Punavuori, and Kamppi, ranging from circa 880 listings $/ \mathrm{km}^{2}$ in Kamppi to circa 1,240 listings $/ \mathrm{km}^{2}$ in Punavuori and nearly 1,650 listings $/ \mathrm{km}^{2}$ in the Torkkelinmäki sub-district in Kallio in 2018 (Figure 1). These neighbourhoods share many characteristics, such as a working-class history and reputation as trendy and artistic neighbourhoods with relatively young populations (see e.g. Mustonen \& Lindblom, 2014). Kallio is located approximately one kilometre north of the city centre and it is a popular housing area among young people. This is largely due to the relatively small size of its apartments, as well as its liberal, bohemian atmosphere and bar scene (Kaakinen, 2013). Kallio is often compared to the trendy and artistic districts of bigger European cities, such as Berlin (e.g. Visit Finland, 2019). Compared to Kallio, Punavuori and Kamppi are generally considered to be more middle-class, mature and polished, mostly because of their location right in the city centre and their status as forerunners of Helsinki's new urban culture and creative industries in the 1990s (Koskinen, 2002; Mustonen \& Lindblom, 2014). Kamppi and Punavuori are nowadays presented in tourism communication as the "design district” of Helsinki. 


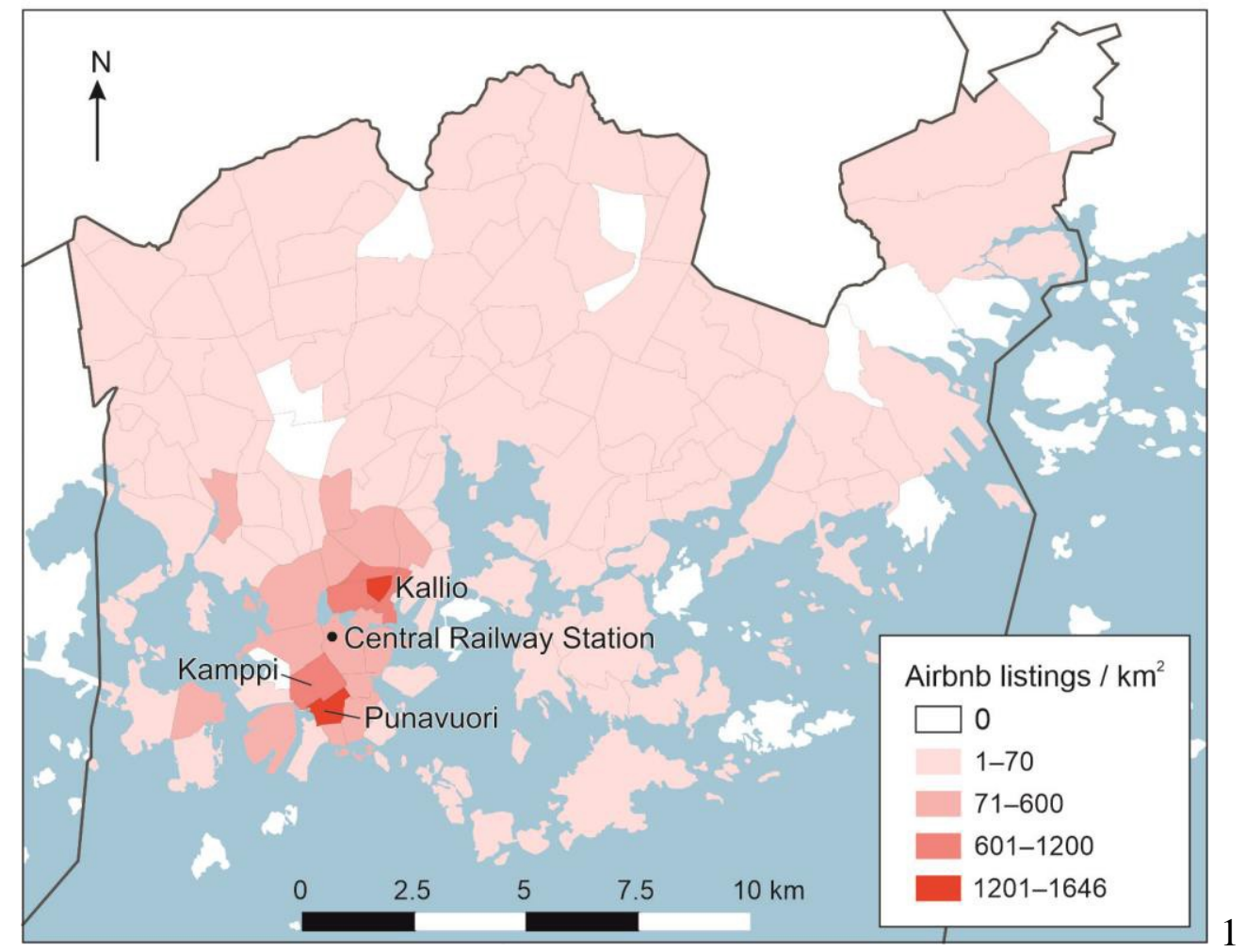

Figure 1. Concentration of Airbnb listings in the sub-districts of Helsinki. The core area of Kallio consists of the sub-districts of Harju, Torkkelinmäki and Linjat. The map is based on the "property match" data collected by AirDNA (https://www.airdna.co) and it includes all Airbnb listings listed in 2018.

The spatial analysis shows how the Airbnbization has spread in the central area of Helsinki. Figure 2 illustrates how the number of reserved Airbnb listings has changed in 200 x 200 metre cells between 2016 and 2019. The maps show an overall increase in the number of reservations, as well as their concentration in the districts of Punavuori, Kamppi and Kallio. The predominance of listings in these three districts is also evident at the street level (figure 3). In addition, there are some streets with a lot of Airbnb activity in the centrally located in the (upper) middle class districts of Töölö and Ullanlinna. 

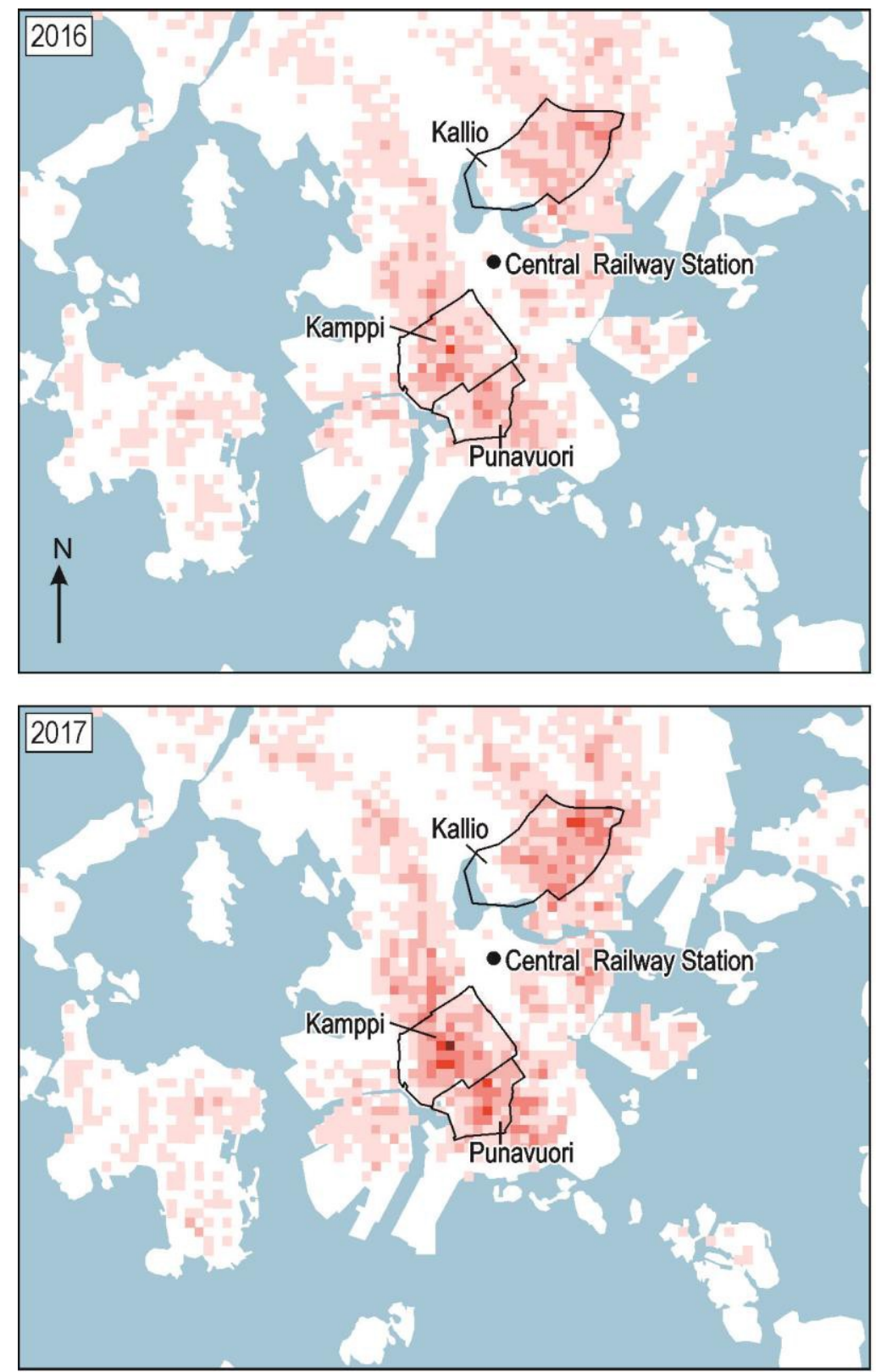

Reserved nights

in $200 \times 200 \mathrm{~m}$ cells
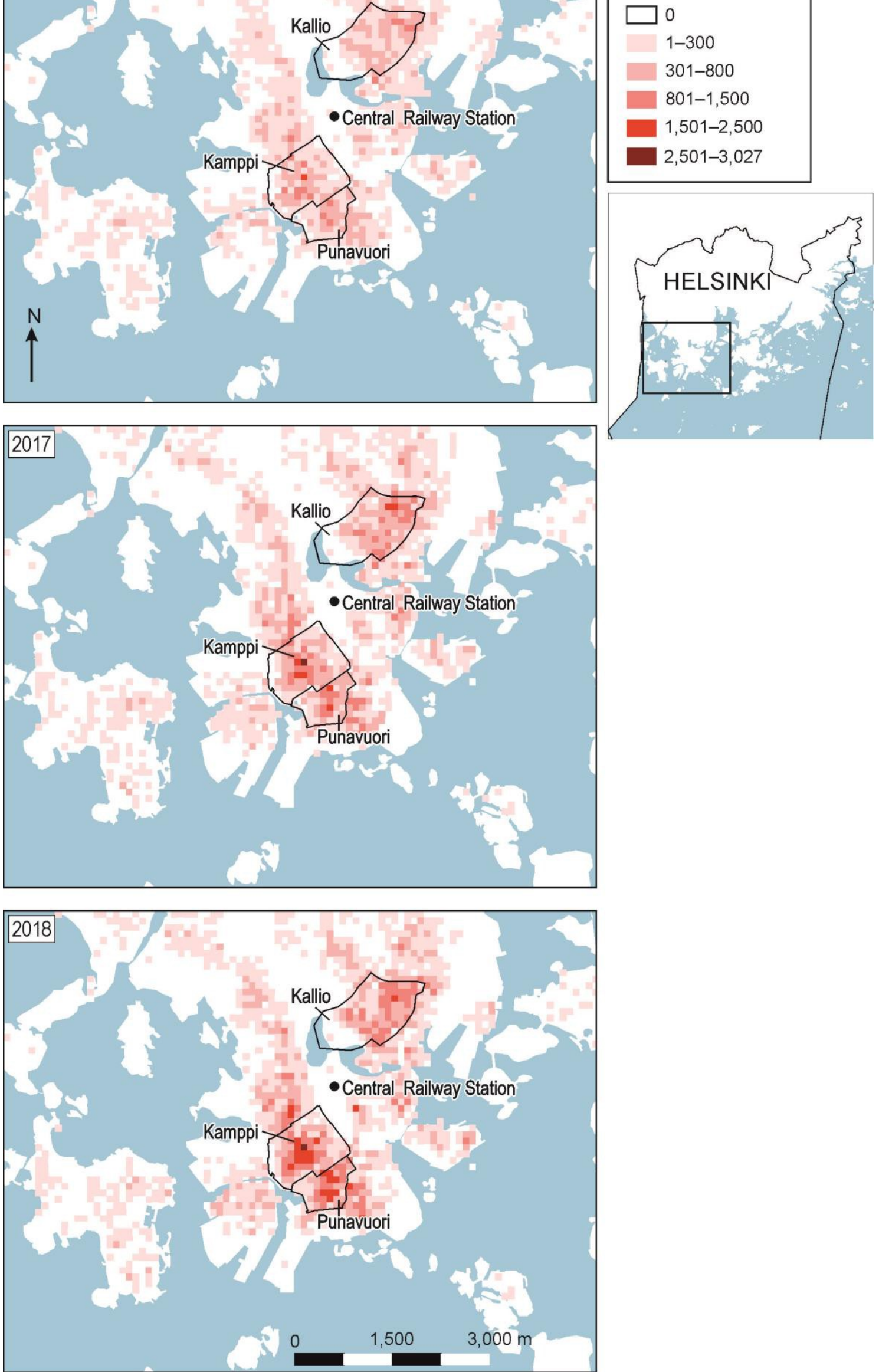
Figure 2. The number of reserved Airbnb nights in 200x200 metre cells in 2016, 2017 and 2018. The map is based on the "monthly match" data collected by AirDNA (https://www.airdna.co).

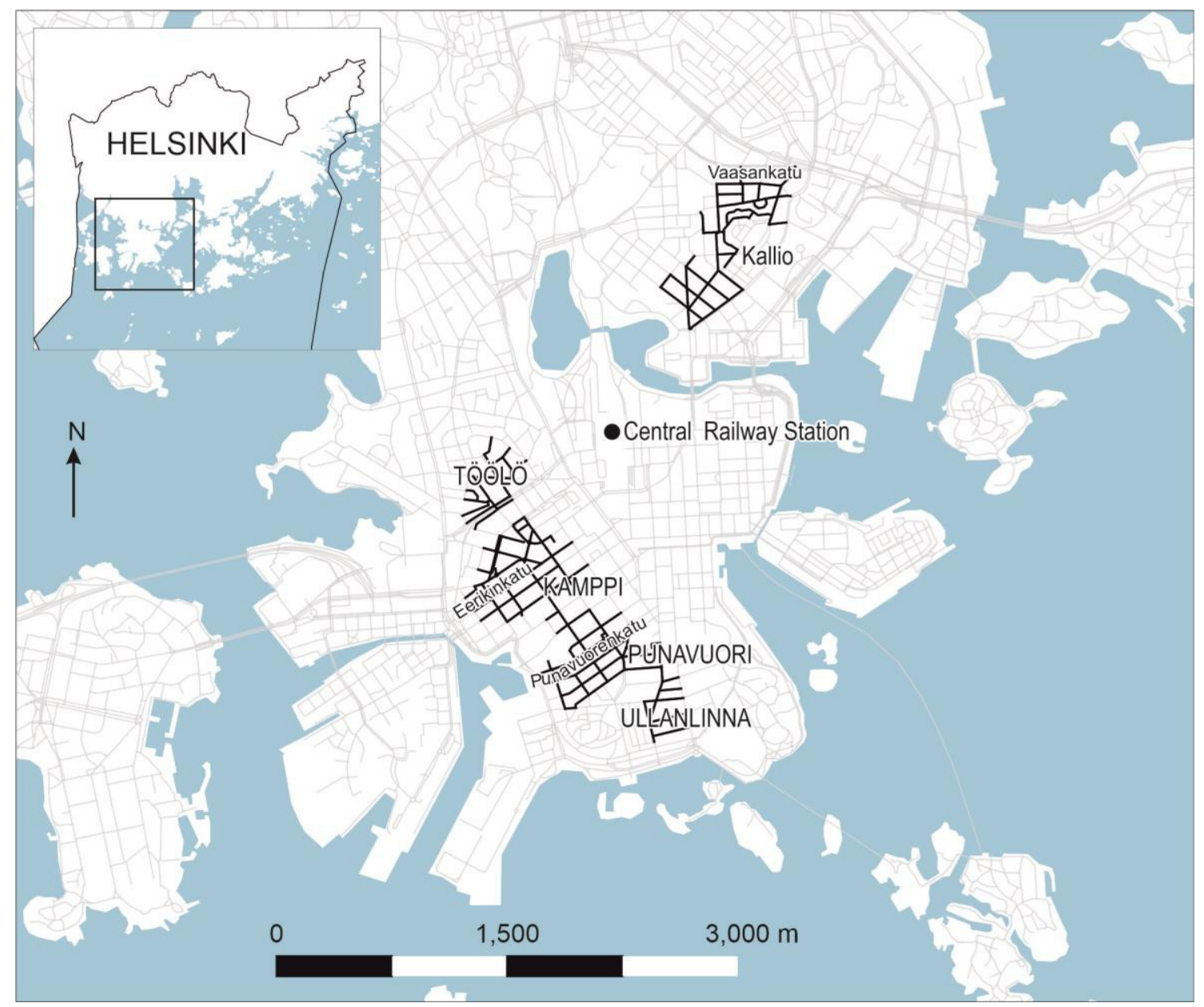

Figure 3. Streets with most Airbnb activity are located in the central urban area of Helsinki and especially in the districts of Punavuori, Kamppi and Kallio. The map is based on the "property match" data collected by AirDNA (https://www.airdna.co) in Helsinki since May 2015 and it includes information of reserved nights in all Airbnb listings in 2018.

These findings support the results of a study by Ioannides et al. (2019), who highlighted the key role of Airbnb in expanding the "tourism bubble" in nascent tourism spaces around the city centre. In their study of the Lombok neighbourhood in Utrecht, they connected the rise of Airbnb to the "neo-bohemian" context in which the working- 
class heritage or old neighbourhoods becomes a resource for artists, cafe owners and other small entrepreneurs in post-Fordist economies (Lloyd, 2006). As Ioannides et al. (2019: 837) put it, a neo-bohemian context "outwardly projects the illusion of ‘edginess’ where non-scripted experiences associated with predictable bubbles are shunned."

Inside the platform: sharing economy or short-rental entrepreneurialism?

Our empirical analysis challenges the idea that short-term rentals of homes in the most visited neighbourhoods of Helsinki correspond to the principles of the sharing economy or is any different from the situation in the more touristic cities of Europe. For this analysis, we used two methods: 1) statistical analysis of AirDNA data for the three selected neighbourhoods between August 2015 and August 2019, looking at: a) the proportion of entire homes within the overall listings; b) the proportion of multiple listings; and c) availability of listings; and 2) qualitative analysis of the Airbnb listings that were visible by simulating a search for an individual room for two nights in the selected areas (12-14 June 2019; two nights, as many listings did not approve requests for one night only; the search was made between 28 and 31 May 2019). The analysis allows some characteristics of the available listings to be seen, as well as of their hosts and guests.

The analysis of the AirDNA data shows that in terms of the type of the listing, a vast majority of the listings in Helsinki have been entire homes/apartments throughout the study period (Table 1). These numbers are representative of the busiest tourism season in Helsinki, as August is the peak month in terms of supply of Airbnb services 
(Mustonen, 2018a, 2018b). In August 2019, for example, the proportion of entire homes/apartments ranged from 83.0\% in the entire city to 91.7\% in Punavuori.

Table 1. Proportion of entire homes/apartments and different type of rooms in August 2015, 2017 and 2019 (https://www.airdna.co).

\begin{tabular}{|l|l|r|r|r|}
\hline KALLIO & & & & \\
\hline Time & $\begin{array}{l}\text { Entire } \\
\text { home/apartment } \\
(\%)\end{array}$ & $\begin{array}{l}\text { Private rooms } \\
(\%)\end{array}$ & $\begin{array}{l}\text { Shared rooms } \\
\text { (\%) }\end{array}$ & $\begin{array}{l}\text { Hotel rooms } \\
(\%)\end{array}$ \\
\hline $8 / 2015$ & $86.5 \%$ & $12.7 \%$ & $0.8 \%$ & 0.0 \\
\hline $8 / 2017$ & $87.5 \%$ & $11.6 \%$ & $0.9 \%$ & 0.0 \\
\hline $8 / 2019$ & $88.1 \%$ & $11.1 \%$ & $0.8 \%$ & 0.0 \\
\hline
\end{tabular}

\begin{tabular}{|l|l|r|l|l|}
\hline KAMPPI & & & & \\
\hline Time & $\begin{array}{l}\text { Entire home/ } \\
\text { apartment (\%) }\end{array}$ & $\begin{array}{l}\text { Private rooms } \\
\text { (\%) }\end{array}$ & $\begin{array}{l}\text { Shared rooms } \\
\text { (\%) }\end{array}$ & $\begin{array}{l}\text { Hotel rooms } \\
\text { (\%) }\end{array}$ \\
\hline $8 / 2015$ & $89.9 \%$ & $8.6 \%$ & $1.4 \%$ & 0.0 \\
\hline $8 / 2017$ & $87.6 \%$ & $11.2 \%$ & $1.2 \%$ & 0.0 \\
\hline $8 / 2019$ & $90.4 \%$ & $8.4 \%$ & $1.1 \%$ & 0.0 \\
\hline
\end{tabular}

\begin{tabular}{|l|l|r|l|l|}
\hline \multicolumn{2}{|l|}{ PUNAVUORI } & & & \multicolumn{2}{l|}{} \\
\hline Time & $\begin{array}{l}\text { Entire home/ } \\
\text { apartment (\%) }\end{array}$ & $\begin{array}{l}\text { Private rooms } \\
\text { (\%) }\end{array}$ & $\begin{array}{l}\text { Shared rooms } \\
\text { (\%) }\end{array}$ & \multicolumn{2}{l|}{$\begin{array}{l}\text { Hotel rooms } \\
\text { (\%) }\end{array}$} \\
\hline $8 / 2015$ & $93.3 \%$ & $4.4 \%$ & $2.2 \%$ & 0.0 \\
\hline $8 / 2017$ & $91.7 \%$ & $7.7 \%$ & $0.6 \%$ & 0.0 \\
\hline $8 / 2019$ & $91.7 \%$ & $7.1 \%$ & $1.0 \%$ & 0.0 \\
\hline
\end{tabular}

\begin{tabular}{|l|l|l|l|lr|}
\hline \multicolumn{2}{|l|}{ ENTIRE HELSINKI } & & & \\
\hline Time & $\begin{array}{l}\text { Entire home/ } \\
\text { apartment (\%) }\end{array}$ & $\begin{array}{l}\text { Private rooms } \\
\text { (\%) }\end{array}$ & $\begin{array}{l}\text { Shared rooms } \\
\text { (\%) }\end{array}$ & $\begin{array}{l}\text { Hotel rooms } \\
\text { (\%) }\end{array}$ \\
\hline $8 / 2015$ & 80.6 & 17.2 & 2.2 & 0.1 \\
\hline $8 / 2017$ & 79.3 & 18.2 & 2.3 & 0.0 \\
\hline $8 / 2019$ & 83.0 & 15.7 & 1.2 & 0.1 \\
\hline
\end{tabular}

Moreover, it is clear that a substantial proportion of the active listings have been either available or reserved for over 60 or even 90 days over the course of year 2018 (Table 2). We also calculated the proportion of active listings that were available or reserved for over 182 days or half a year. These thresholds reveal the difference 
between the use of apartments mostly occupied by residents and offered during short vacancy periods, and the use of second homes or professional rental services. This information is important when defining whether Airbnb listings can become disruptive to the social fabric of a neighbourhood. Local administrations in other cities have therefore made agreements with Airbnb on either of "60-night" or "90-night" rule as a legal limit for the use of homes in short rentals (e.g.:

https://www.airbnb.co.uk/help/article/1379/responsible-hosting-in-the-united-kingdom).

Table 2. The number of active Airbnb listings and the percentage of those listings that had over 60 and 182 available or reserved days in 2018 (https://www.airdna.co).

\begin{tabular}{|l|l|r|r|r|}
\hline & $\begin{array}{l}\text { Number of } \\
\text { active } \\
\text { properties }\end{array}$ & $\begin{array}{l}\text { Properties with } \\
\text { over 60 available or } \\
\text { reserved days (\%) }\end{array}$ & $\begin{array}{l}\text { Properties with } \\
\text { over 90 available or } \\
\text { reserved days (\%) }\end{array}$ & $\begin{array}{l}\text { Properties with } \\
\text { over 182 available } \\
\text { or reserved days } \\
\text { (\%) }\end{array}$ \\
\hline Kallio & 971 & $48.7 \%$ & $41.2 \%$ & $20.2 \%$ \\
\hline Kamppi & 690 & $63.6 \%$ & $54.9 \%$ & $23.6 \%$ \\
\hline Punavuori & 482 & $57.9 \%$ & $48.8 \%$ & $22.0 \%$ \\
\hline $\begin{array}{l}\text { Entire } \\
\text { Helsinki }\end{array}$ & 7077 & $50.0 \%$ & $41.4 \%$ & $22 \%$ \\
\hline
\end{tabular}

Furthermore, AirDNA’s data show that in August 2019, a relevant proportion (18.5\%) of the hosts who had a listing in Kallio, Kamppi or Punavuori, had also other listings in Helsinki. The percentage of hosts with two or more listings in Helsinki ranged from $14.5 \%$ in Kallio to $21.6 \%$ in Punavuori and $23.7 \%$ in Kamppi, as compared to $11.7 \%$ across the whole city. In addition, when the percentage of hosts with two or more listings in these neighbourhoods is compared, there has been an upward trend between 2015 and 2019, with the highest increase in Punavuori.

This matter of multiple listings can be further explored by looking at singular hosts associated to the offers in the Airbnb platform. According to our qualitative analysis of hosts of multiple listings offered in the areas under focus, few of them are 
explicitly introduced as professional. Most of the hosts do not clearly mention their own professionalism but rather portray themselves as young (generally, in their 30s) travellovers, creative, hospitable and open-minded individuals, and navigating into stories of cosmopolitan selves "sharing” homes and homely experiences with their guests. These self-presentations show common characteristics that have been illustrated by Roelofsen (2018) as a strategy of commodification of "home”.

Table 3 presents a list of hosts we found by searching through the available listings in Punavuori, Kamppi and Kallio, who also manage other apartments, either in these same neighbourhoods or elsewhere. While we have indicated the names of the registered companies, we have anonymized those that appear as individual persons. The numbers shown in the table, surely underestimated as they are based on the listings available on the days of our query, do challenge the perception of non-professionalism in this sector and prove that apartments are economic assets, in some cases concentrated in the hands of a small number of professional enterprises. The profitability of shortterm home rentals is also proved by the size and type of offered listings: mostly studios or, in fewer cases, one bedroom apartments with at least three beds, sometimes including options of inflatable mats, at prices varying in proportion to the number of guests. In most cases, there is no personal contact between hosts and guests, as everything is regulated online, and keys are handled through intermediaries, or local shops (e.g. in the central railway station) or security boxes, or door opening is by entry codes.

Table 3. Hosts with multiple listings in May 2019.

\begin{tabular}{|l|r|}
\hline Host name & $\begin{array}{r}\text { Number of listings } \\
\text { managed by the host }\end{array}$ \\
\hline Hiisi Homes & 129 \\
\hline Roost & 82 \\
\hline
\end{tabular}




\begin{tabular}{|l|r|}
\hline WeHost & 61 \\
\hline I. & 47 \\
\hline 2ndhomes & 36 \\
\hline F. & 31 \\
\hline Forenom & 29 \\
\hline K. & 12 \\
\hline Solakalliontie & 11 \\
\hline A. & 8 \\
\hline L. & 8 \\
\hline M. & 7 \\
\hline K. & 7 \\
\hline S. & 6 \\
\hline L. & 6 \\
\hline T. & 4 \\
\hline R. & 3 \\
\hline M. & 3 \\
\hline J. & 2 \\
\hline O. & 2 \\
\hline A. & 2 \\
\hline E. & 2 \\
\hline S. & 2 \\
\hline
\end{tabular}

These results depict the presence of a hidden tourist economy capitalization of residential housing, and especially of small flats. Homes are handled for extractive rather than sharing economy interests. Therefore, it is important to question the truths of the self-presentation of the individuals offering homes in Airbnb, and their relationship with the apartments they handle. Are the hosts and "superhosts" portrayed in the platform the real owners or tenants of the offered listings, or are they employees dealing with multiple listings on behalf of other entrepreneurs? Consequently, we can doubt that these short-term rental activities have the function of supporting family incomes, as they are more likely to be assimilated into estate enterprises.

Future studies will need then to assess their impacts on the housing market and neighbourhoods relations. Therefore, they will need to support closer monitoring and 
regulation of these phenomena, as is claimed in other situations, where Airbnb is recognized as a gentrifying driver (Arias Sans and Quaglieri Dominguez, 2016; Cócola Gant, 2016; Wachsmuth and Weisler, 2018).

\section{Residents’ perceptions}

According to a report produced by the City of Helsinki, local residents have positive attitudes towards tourism, as it increases Helsinki’s vitality and internationality (City of Helsinki, 2019). Through its survey, it indicates that for 70\% of the respondents, Helsinki benefits from tourism growth; while for only $20 \%$ did it have any negative effect on their living environment; and for $25 \%$, congestion has affected the most touristic areas of Senate Square, Market Square and Suomenlinna Island. A study based on tourists’ perceptions confirmed the same ideas (Paananen and Minoia, 2018). Attitudes to apartment rentals are also generally positive, even in the districts of Kallio, Kamppi and Punavuori (City of Helsinki, 2019).

More specifically on short rentals for tourism, no studies have been produced so far. Our analysis of residents' perceptions is based on informal conversations in multiple venues and occasions, either informal or in organized meetings with residents' representatives and officers working of the local administration.

A city official involved in the planning of Helsinki’s housing policy confirms that while the price of housing is an issue under debate in Helsinki, there are no prominent protest movements around Airbnb or other housing issues in the city (conversation held on 23 April, 2020). In Kallio, the responses and lack of activism by the residents, according to a representative of Kallio residents' association (June 7, 
2019), can be explained in terms of structural reasons related to the type of housing and population in Kallio. According to him, more than $60 \%$ of the apartments are rented to young tenants by investors who do not live in Kallio themselves; and tenants do not participate in the housing cooperatives' meetings. The rapid turnover of the residents makes them loosely attached to the place, which would cause many houses in Kallio to “lose their locality.” This situation where "people come and go" is accelerated by Airbnb that encourages people to use their apartments for profit, instead of nurturing local culture and rootedness. In the worst case, this may lead to the emergence of "house hotels" - ordinary houses that are used to accommodate tourists - and to other related problems: for example, unsafety due to unregulated delivery of keys to Airbnb guests; missed payments for the water and electricity used; or water damage increasing the maintenance costs of housing companies. For the Kallio representative, civic activism and community involvement (see e.g. Kaakinen, 2013 on conservative Kallio residents against public drinking) take a long time to form and instead, it should be the local government's duty to play an active role in defining a clear boundary between professional accommodation services and housing. In addition, existing detailed plans should be used as a tool when evaluating activities in individual houses: when an area of land has been designated for housing, it should not be used for commercial purposes such as the accommodation of tourists.

On the other hand, despite Punavuori's situation, a resident representative (October 14, 2019) confirmed the general positive perception of Airbnb as a convenient means for using homes during vacation times, and for meeting fluctuating demands for beds during the year; and admits that she is a host herself. For her, there is no risk of excessive exploitation at the expense of residential homes, as short rentals are not so profitable compared to downtown long-term rentals that are pricy already. Inappropriate 
uses of apartments would be contested by residents, like in the case of a "secret hotel" that was reported and closed. She had not heard of any problematic issues, such as disturbance in the buildings or misuse of common spaces and does not think that a high turnover of guests in the premises represents a particular risk.

While she believes in liberal principles and that no restrictions to the use of platforms should be applied, another Punavuori representative, who is also a recognized activist for the preservation of the neighbourhood, elaborated on some structural challenges. For instance, since apartments in Helsinki are owned by shareholders of housing cooperatives, damage caused by frequent renting by one shareholder can be problematic for the others, who also have to pay for repairs. In the long term, this could break the very cooperative relations that are at the core of housing traditions in Helsinki. Moreover, many apartments are in the hands of investors, and like in Kallio, she saw few people participate in cooperative meetings. However, residents are generally tolerant and more interested in positive campaigning and therefore, it would be hard to create any movement against Airbnb.

\section{Perceptions and responses by the public representatives}

Local and national authorities have reacted positively to the growing popularity of digital short-term rental platforms. While appreciating digital platforms generally as opportunities for small companies and entrepreneurs to gain access to the international market (Virkkunen \& Kosonen, 2018), these authorities also see them as a way to increase the very limited accommodation capacity provided in the country and particularly, in the capital city. Nevertheless, the Ministry of Economic Affairs and 
Employment recognizes the need to study and address new regulatory challenges of the sharing economy regulatory environment, via flexible mechanisms that would encourage different actors to enter the market, enabling the renewal of tourism businesses (Ministry of Economic Affairs and Employment, 2017; Laitinen, 2019). This would enhance Finland's competitiveness and business opportunities by addressing issues like "gaining entry to the market, taxation, employment, liability regimes, consumer protection and competition” (Ministry of Economic Affairs and Employment, 2019, p. 9). A major question concerning the development of the regulatory environment is related to the ambiguity of definitions. For example, the definition of a "professional accommodation service” is crucial for determining regulation and taxation boundaries of the different categories that intervene in the platform economy. Similarly, representatives of Finland's Tax Administration acknowledge that regulation of the platform economy needs to be developed; but instead of taking immediate action, they emphasize that it is important to gain more information on the ways in which different actors may utilize the opportunities offered by digital platforms (Varonen, 2019).

The positive attitude has also been shared at the local level. In 2018, for example, Anni Sinnemäki, Deputy Mayor for Urban Environment in Helsinki said that Airbnb's operation and effects in Helsinki should be observed and rules of the game discussed, but not urgently, because Helsinki has not witnessed large-scale escalated problems yet, but only a few issues at the level of individual housing cooperatives (Koivuranta, 2018). Similar feedback has come from other actors in the field, as reported by Jukka Punamäki, Senior Advisor of the City for tourism-related issues (conversations held in June 2018 and October 2019), who has, for example, facilitated a discussion event with representatives of the City of Helsinki, interested organizations (e.g. Finnish Tenants, the Finnish Landlord Association), state administration (e.g. The 
Housing Finance and Development Centre of Finland, Tax Administration), and shortterm rental business (e.g. WeHost, Forenom).

Within the City administration, the Economic Development department with the main responsibility for tourism has generally been unwilling to intervene in the functioning of the market. By contrast, the Urban Environment Division has been more concerned about maintaining a balance between tourism accommodation and housing in the central area of Helsinki. In the same vein, Helsinki’s Building Control Services has recently introduced guidelines that clarify the definition of acceptable short-term renting of a flat (City of Helsinki, 2020). These guidelines outline that housing cooperatives and share owners are responsible for ensuring that flats are used for those purposes that are defined in their respective buildings' building permits.

The new guidelines are essentially a response to residents’ inquiries and requests for action following a recent case in which Helsinki’s Urban Environment Committee intervened against Easy Homes Helsinki Oy and a housing cooperative in Punavuori, where several apartments were offered on short-term rentals. The city ordered them to stop offering accommodation services in the building by May 1, 2019, on pain of a fine. The decision was based on an interpretation that the accommodation services were undoubtedly professional, and that a building permit would have been needed since the building was designated for residential use. Thus, at least until recently, the understanding of platform tourism as an overall positive trend that is not generating problems has justified an approach of cultural trust in a progressive and neoliberal-open society, with minimum case-by-case reaction.

Instead of focusing directly on the problems related to short-term-rentals, the City of Helsinki has attempted to use housing policy to tackle some of the problems 
related to the purchasing of small apartments by investors, as well as related high turnover of residents, followed by the loosening of residents' attachment to their neighbourhood. The City of Helsinki is a strong housing policy actor, because it owns nearly two thirds of its land area (City of Helsinki, 2018). Thus, it is able to regulate the composition of different types of flats in new housing units, avoiding the situation in Kallio and Punavuori where a relatively large proportion of buildings consist of small apartments that are favoured by short-term residents and tourists. For example, the housing policy of the City of Helsinki outlines that $40-50 \%$ of the permitted building area in new non-subsidised owner-occupied housing unites should be dedicated for use as family homes with a minimum of two bedrooms (City of Helsinki, 2016).

Following Das Acevedo’s (2016) platform’s regulating categories: “regulate it out of existence”; “don’t regulate it at all”; and "wait-and-see", we can say that the responses by Finland's public authorities have mainly fallen into the third category, reflecting the idea that strict regulation might harm the development of Finland's tourism sector, while social problems are not (yet) being felt. While the new guidelines introduced by the City of Helsinki and the landmark ruling concerning Easy Homes Helsinki Oy clarify the boundary between professional and non-professional offerings, it remains to be seen how unacceptable short-term renting will be monitored and regulated in practice (Oksanen 2020).

\section{Conclusions}

Our paper has proposed an empirical study to analyse the situation of the growing Airbnbzation of Helsinki, its spatial distribution, and the perception by residents and 
local administrative officers. Through a multi-method analysis of spatial and qualitative nature, we have been able to follow the latest progress of the phenomenon by using AirDNA historical data, direct observation of listings and other qualitative analysis of media, policy documents, and regulations. Moreover, this study has direct policy implication as some issues were discussed with various parties involved in the topic.

The aim of this study was to provide evidence about the way in which the phenomenon of short-term rentals has developed in Helsinki, despite a generally positive acceptance on platforms as mediators of lodging, and minor acknowledgments about their impacts on housing rights. Based on our presence in the city as residents, and our observation of the growing number of platform-offered listings in the central areas of the city, we consider that the lack of public discussion was not sufficient to suggest the non-relevance of such a study. On the contrary, we argue that the absence of Helsinki on an international dataset like InsideAirbnb, is motivated by a low acknowledgement about the problem. Thus, there is a need for baseline spatial analysis and a qualitative survey on multiple listings. Other GIS databases, e.g. on services or infrastructure, will be overlaid in future studies. These may reveal different interesting changing patterns in spatial connections between short-term rental listings and their surroundings.

In this study, we have shown that in Helsinki, the rise of digital short-term rental platforms is especially pronounced in Kallio, Kamppi and Punavuori, old working-class districts with a liberal atmosphere and trendy urban culture. The public discourse has portrayed the rise of digital tourism services as a seemingly technical question related to the attractiveness and fairness of Finland's business environment; and until now, the City of Helsinki has adopted a "wait-and-see" (Acevedo, 2016) attitude towards the 
growing popularity of Airbnb and other digital short-term rental platforms. At the same time, the city has actively promoted a culture that has emphasized deregulation in the form of "the removal of unnecessary obstacles that hinder encounters and actions with impact” with the purpose of encouraging value production through individual (entrepreneurial) activity, as well as the promotion of authenticity and lively urban culture (Jokela, 2019; Helsinki Brand Concept, 2016).

Some visible effects are evident in the central areas we observed, especially in terms of public spaces that have lost their previous local intimacy to become open, commercial and extrovert; but eventual deeper consequences at the level of individual residents and neighbourhoods are yet to be explored. The result of the empirical observation has shown the existence of trends that controvert the idea of the platform as enabling housing offers by local residents in a non-professional manner and as complementing the need for more beds for a growing number of tourists arriving in Helsinki.

However, very recently, the local authorities have expressed a new interest in finally attending politically to the "silent” expansion of Airbnb, something that has been long overlooked. Events like the "silent hotel” in Punavuori in a residential building, and the presence of growing entrepreneurial profits through short-term rentals against the housing crunch in Helsinki, have started calls for renewed attention to the operation of rental platforms through guidelines on the provision of accommodation in flats (City of Helsinki, 2020). These new regulations have not yet been applied during this time of the Covid-19 pandemic; therefore, it will be interesting to see how they will interact with these so far-uncontrolled, internet-based home rentals. 


\section{References}

Acevedo, D. D. (2016). Regulating employment relationships in the sharing economy. Employee Rights and Employment Policy Journal, 20, 1-35.

Airbnb (2019, June 3). Forenom becomes Airbnb’s largest Serviced Apartment partner in the Nordics. Retrieved from https://www.forenom.com/news/the-nordicregions-leading-business-accommodation-provider-forenom-becomes-airbnbslargest-serviced-apartment-partner-in-the-nordics/

Arias Sans, A. \& Quaglieri Domínguez, A. (2016). Unravelling Airbnb: Urban perspectives from Barcelona. in Russo P. and Richards, G. (eds) Reinventing the Local in Tourism: Producing, Consuming and Negotiating Place.

Bristol/Buffalo: Channel View Publications, pp. 209-228.

City of Helsinki (2016, September 27). Kotikaupunkina Helsinki [Home town Helsinki]. Implementation programme on housing and related land use. Retrieved from http://www.hel.fi/static/kanslia/Julkaisut/KotikaupunkinaHelsinki/2016/am-ohjelma2016_fi_low.pdf

City of Helsinki (2018, 11 December). Helsinki facts and figures. Retrieved from https://www.hel.fi/hel2/tietokeskus/julkaisut/pdf/18_12_11_tasku18_en_net.pdf

City of Helsinki (2020, April 9). City of Helsinki issues guidelines on the provision of accommodation in apartments. Retrieved from https://www.hel.fi/uutiset/en/kaupunkiymparisto/guidelines-on-the-provision-ofaccommodation-in-flats

City of Helsinki (2019, May 31). Valtaosa helsinkiläisistä näkee alueelle suuuntautuvan matkailun elinvoimaa ja kansainvälisyyttä lisäävänä tekijänä [Majority of Helsinkians views tourism in the area as a factor that increases 
vitality and internationality]. Retrieved from

https://www.hel.fi/uutiset/fi/kaupunginkanslia/valtaosa-helsinkilaisista-nakeealueelle-suuntautuvan-matkailun-elinvoimaa-ja-kansainvalisyytta-lisaavanatekijana

City of Helsinki Executive Office (2019, October 13). Helsinki’s present state and development 2019. Retrieved from https://www.hel.fi/hel2/tietokeskus/julkaisut/pdf/19_08_27_Helsinkis_presentst ate_and_development_2019.pdf

Cócola Gant, A (2016) Holiday rentals: The new gentrification battlefront. Sociological Research Online 21(3):112-120.

Cócola, Gant, A \& Gago, A. (2019). Airbnb, buy-to-let investment and tourism-driven displacement: A case study in Lisbon. EPA: Economy and Space (online) DOI: 10.1177/0308518X19869012

Crouch C. (2016). The Paradoxes of Privatisation and Public Service Outsourcing. The Political Quarterly, 86(S1), 156-171.

Evans, M. (1988). Participant observation. In J. Eyles and D. Smith (Eds.), Qualitative Methods in Human Geography (pp. 197-218). Cambridge: Polity.

Haraway, D. (1996). Situated knowledges: The science question in feminism and the privilege or partial perspective. In J. Agnew, D. Livingstone \& A. Rogers (Eds.), Human Geography: An Essential Anthology (pp. 108-128. Malden, MA: Backwell Publishing.

Helsinki brand concept (2016, 12 January). Kuudes Kerros \& City of Helsinki. Retrieved from http://www.brandnewhelsinki.fi/2020/ Häkli, J. (2005). Who is the Finn?: Globalization and Identity in Finland. Journal of Finnish Studies, 9(2), 12-26. 
Hilson, M. (2008). The Nordic Model: Scandinavia since 1945. London: Reaktion books

Ioannides, D., Röslmaier, M. \& van der Zee, E. (2019). Airbnb as an instigator of ‘tourism bubble’ expansion in Utrecht's Lombok neighbourhood. Tourism Geographies, 21(5), 822-840.

Jokela, S. (2019). Transformative city branding and the evolution of the entrepreneurial city: The case of 'Brand New Helsinki'. Urban Studies, 1-16, DOI: $10.1177 / 0042098019867073$

Jonung, L, Kiander, J. \& Vartia, P. (2009). The great financial crisis in Finland and Sweden: the dynamics of boom, bust and recovery 1985-2000. In L. Jonung, J. Kiander \& P. Vartia (Eds.), The great financial crisis in Finland and Sweden: The Nordic experience of financial liberation (pp. 19-70). Cheltenham, Edward Elgar.

Julkunen, R. (2006). Kuka vastaa? Hyvinvointivaltion rajat ja julkinen vastuu. Helsinki: Gummerus Kirjapaino

Kaakinen I. (2013). Julkijuominen, julkisten tilojen sääntely ja Karhupuiston käytöskukat [Taming the Bear Park: drinking, drunkenness and public space management through community involvement]. Alue ja Ympäristö, 42(2), 1729.

Kiander, J. (2001). Laman opetukset: Suomen 1990-luvun kriisin syyt ja seuraukset [Lessons from the depression: the causes and consequences of Finland's crisis in the 1990s]. VATT Publications 27:5.

Koivuranta, E. (2018, April 18). Alkaako Helsinki suitsia Airbnb majoittajien toimintaa? Apulaispormestari Sinnemäen mielestä rajoituksille ei ole vielä tarvetta [Will Helsinki curb the operation of Airbnb accommodators? Deputy 
Mayor Sinnemäki maintains that there is no need for regulation yet]. Yle.

Retrieved from https://yle.fi/uutiset/3-10165621

Koskinen, I. (2002). Semiotic Neighborhoods: The Case of Helsinki

(Kuluttajatutkimuskeskuksen työselosteita ja esitelmiä 73/2002). Retrieved from https://helda.helsinki.fi/bitstream/handle/10138/152324/Semiotic_neighborhood s.pdf?sequence $=1$

Laakso M. (2020, April 24). Airbnb-emäntä Katja Meriläiseltä katosivat melkein kaikki asiakkaat - mutta Espoon-mökille on tunkua [Airbnb host Katja Meriläinen lost almost all her clients - but people are crushing to the cottage in Espoo], Helsingin Sanomat 24.4.2020 Retrieved from https://www.hs.fi/koti/art2000006485470.html

Laitinen, A. (2019, May 14). Jakamistalous: toimenpiteet TEM:issä [Sharing economy: action in the Finnish Ministry of Economic Affairs and Employment] [A presentation in a tourism seminar organized by the Finnish Ministry of Economic Affairs and Employment in Helsinki].

Landry, C. (2000). The creative city: A toolkit for urban innovators. Abingdon, Oxon: Earthscan.

Lloyd, R. (2006). Neo-Bohemia: Art and commerce in the postindustrial city. New York, NY: Routledge.

Ministry of Economic Affairs and Employment (2017). Jakamistalouden säädösympäristö: Haasteet ja kehittämistarpeet [Sharing economy regulatory environment - Challenges and developmental needs] (TEM reports 44/2017). Helsinki: Author.

Ministry of Economic Affairs and Employment (2019, May 16). Yhdessä enemmän: Kestävää kasvua ja uudistumista Suomen matkailuun [Achieving more together: 
The Roadmap for Growth and Renewal in Finnish Tourism]. A draft of Finland's tourism strategy 2019-2028 and strategic action. Helsinki: Author.

Martin, C. J. (2016). The sharing economy: A pathway to sustainability or a nightmarish form of neoliberal capitalism? Ecological Economics, 121, 149159.

Michelsen, K.-E. \& Kuisma, M. (1992). Nationalism and industrial development in Finland. Business and Economic History, 21, 343-353.

Mosedale J. (2016). Neoliberalism and the political economy of tourism: Projects, discourses and practices. In J. Mosedale (Ed.), Neoliberalism and the political economy of tourism (pp. 1-20). London: Routledge.

Mustonen, P. (2015, June 2). How Helsinki became a trailblazer in urban culture. Helsinki Quarterly 4/2014. Retrieved from https://www.kvartti.fi/en/articles/how-helsinki-became-trailblazer-urban-culture

Mustonen, P. (2018a, August 3). Airbnb:n tarjonta kattaa jo viidenneksen Helsingin majoituspaikoista [Airbnb covers already one fifth of Helsinki’s accommodation capacity]. Retrieved from https://www.kvartti.fi/en/node/643

Mustonen, P. (2018b). Helsinki tourism enjoys a record-breaking year - but what next? Quarterly 2/2018. Retrieved from https://www.kvartti.fi/en/articles/helsinki-tourism-enjoys-record-breaking-yearwhat-next

Mustonen, P. \& Lindblom, T. (2014). Creative districts of Helsinki. In L. Marques \& G. Richards, G. (Eds.), Creative districts around the world. Breda: CELTH/NHTV. Retrieved from http://creativedistricts.imem.nl Mäenpää, P. (2005) Narkissos kaupungissa: Kuluttaja-kaupunkilainen ja julkinen tila [Narcissos in the city: Consumer-citizen and public space]. Helsinki: Tammi. 
Nenakhova, Y. (2018). Challenges and Opportunities of Hotels in Helsinki Regarding Airbnb (thesis). Saimaa University of Applied Sciences. Retrieved from https://www.theseus.fi/bitstream/handle/10024/169128/Nenakhova_Yulia.pdf?se quence $=2$ \&isAllowed $=\mathrm{y}$

Oksanen, K. (2020, February 3). Uusi, tiukka Airbnb-ohjeistus ei vakuuta kiinteistöalaa: ”Helsingin kanta on mustavalkoinen” [The new, strict Airbnb guidelines do not convince property business: “Helsinki’s standpoint is too black-and-white”]. Helsingin Sanomat. Retrieved from https://www.hs.fi/kaupunki/art-2000006394427.html

Paananen K. \& Minoia P. (2018). Cruisers in the City of Helsinki: Staging the mobility of cruise passengers. Tourism Geographies. Advance online publication. https://doi.org/10.1080/14616688.2018.1490341

Pajuriutta, S. (2019, June 13). Helsingin Kivinokan mökkiyhteisössä kuohuu: Airbnbilmiö valtasi kesämaja-alueen [The cottage society in Helsinki's Kivinokka is in a state of ferment: Airbnb phenomenon captured the summer lodge area].

Helsingin Sanomat. Retrieved from https://www.hs.fi/kaupunki/art$\underline{2000006140874 . h t m l}$

Raento, P. (2009). Tourism, nation, and the postage stamp: Examples from Finland. Annals of Tourism Research, 36(1), 124-148.

Roelofsen, M. (2018). Performing "home” in the sharing economies of tourism: the Airbnb experience in Sofia, Bulgaria. Fennia 196(1) 24-42

Rose, G. (1997). Situating knowledges: Positionality, reflexivities and other tactics. Progress in Human Geography, 21(3), 305-320.

Rose, N. (1999). Powers of Freedom: Reframing Political Thought. Cambridge: Cambridge University Press. 
Saastamoinen, A. (2020). Ville tarjoaa vuokralle karanteenikotia Vantaalta: "Vaaleat pinnat niin ei rupea ahdistamaan" [Ville offers a quarantine home for rent in Vantaa: “Light surfaces don't start to bother you”]. Iltalehti 21.03.2020. Retrieved from https://www.iltalehti.fi/koronavirus/a/c33cd41a-2db0-4d2d9a24-ff39eb9840bf

Schienstock, G. (2007). From path dependency to path creation: Finland on its way to the knowledge-based economy. Current Sociology, 55(1), 92-109.

Varonen, S. (2019, May 14). Sharing economy from the perspective of Finnish Tax Administration [Commentary in a panel discussion in a tourism seminar organized by the Finnish Ministry of Economic Affairs and Employment in Helsinki].

Visit Finland (2019, June 5). Kallio: A vibrant Helsinki district. Retrieved from https://www.visitfinland.com/article/vibrant-helsinki-district-kallio/

Virkkunen, P. \& Kosonen K. (2018, March 2). Matkailun digitalisointi on mahdollisuus, johon on tartuttava [The digitalization of tourism is an opportunity that should be seized]. Retrieved from https://www.businessfinland.fi/ajankohtaista/blogs/2018/matkailundigitalisointi-on-mahdollisuus-johon-on-tartuttava/

Wachsmuth, D. \& Weisler, A. (2018). Airbnb and the rent gap: Gentrification through the sharing economy. Environment and Planning A: Economy and Space, 50(6), $1147-1170$ 
Acknowledgements: We would like to thank Research Assistant Jasmiina Myllys for helping us with the analysis of the AirDNA data and Pekka Mustonen, Jukka Punamäki and Elina Eskelä for their valuable insights on the research topic. We are also grateful for the Faculty of Social Sciences at the University of Helsinki and Academy of Finland (RELATE Centre of Excellence 2017-2019, grant number 307348) for supporting this research. Finally, we would like to express our gratitude to the two anonymous reviewers, whose comments helped us to improve the paper. 